Prepared for the U.S. Department of Energy

under Contract DE-AC05-76RL01830

\title{
Financial Metrics Data Collection Protocol, Version 1.0
}

KM Fowler

WJ Gorrissen

N Wang

April 2010

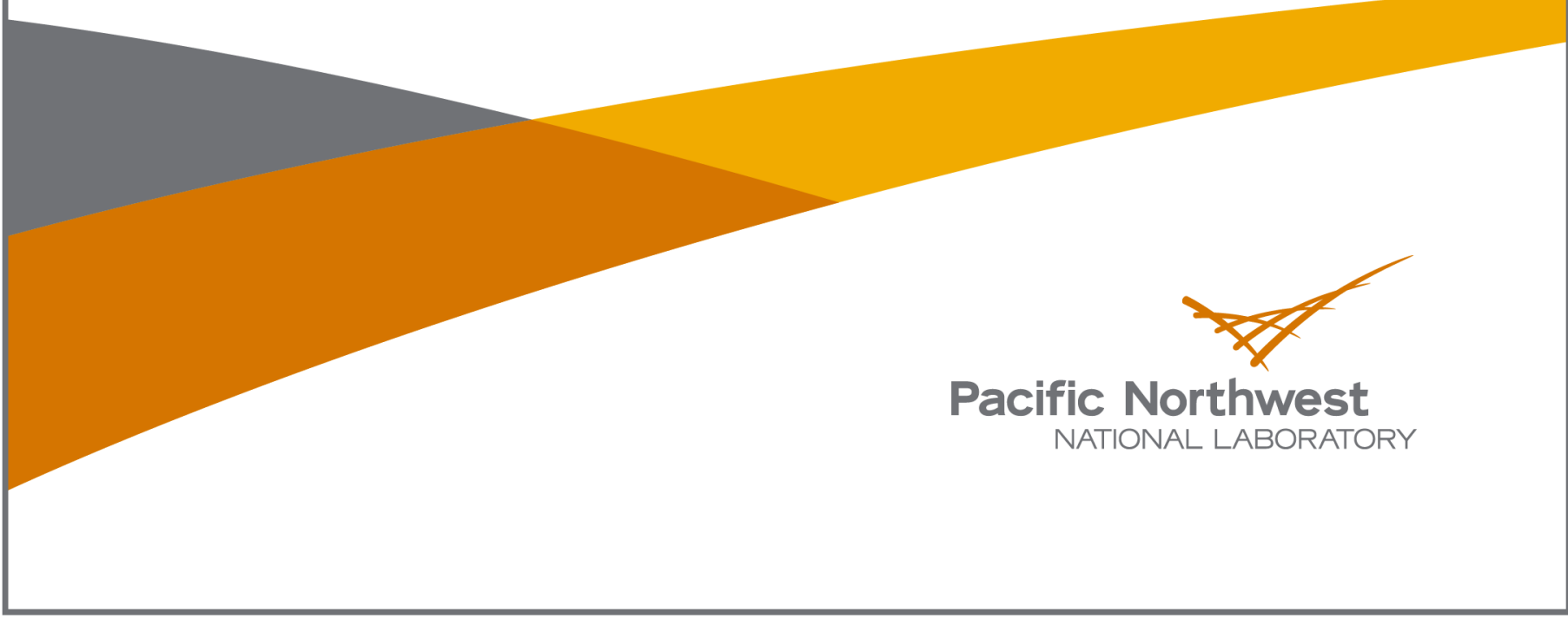




\title{
DISCLAIMER
}

This report was prepared as an account of work sponsored by an agency of the United States Government. Neither the United States Government nor any agency thereof, nor Battelle Memorial Institute, nor any of their employees, makes any warranty, express or implied, or assumes any legal liability or responsibility for the accuracy, completeness, or usefulness of any information, apparatus, product, or process disclosed, or represents that its use would not infringe privately owned rights. Reference herein to any specific commercial product, process, or service by trade name, trademark, manufacturer, or otherwise does not necessarily constitute or imply its endorsement, recommendation, or favoring by the United States Government or any agency thereof, or Battelle Memorial Institute. The views and opinions of authors expressed herein do not necessarily state or reflect those of the United States Government or any agency thereof.

\author{
PACIFIC NORTHWEST NATIONAL LABORATORY \\ operated by \\ BATTELLE \\ for the \\ UNITED STATES DEPARTMENT OF ENERGY \\ under Contract DE-AC05-76RL01830
}

Printed in the United States of America
Available to DOE and DOE contractors from the Office of Scientific and Technical Information,
P.O. Box 62, Oak Ridge, TN 37831-0062;
ph: (865) 576-8401
fax: $(865)$ 576-5728
email: reports@adonis.osti.gov

\begin{abstract}
Available to the public from the National Technical Information Service, U.S. Department of Commerce, 5285 Port Royal Rd., Springfield, VA 22161 ph: (800) 553-6847 fax: $(703) 605-6900$ email: orders@ntis.fedworld.gov online ordering: http://www.ntis.gov/ordering.htm
\end{abstract}

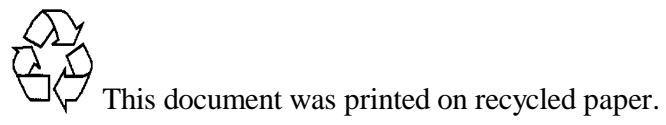




\section{Financial Metrics Data Collection Protocol, Version 1.0}

KM Fowler

WJ Gorrissen

$\mathrm{N}$ Wang

April 2010

Prepared for the U.S. Department of Energy

under Contract DE-AC05-76RL01830

Pacific Northwest National Laboratory

Richland, Washington 99352 


\section{Contents}

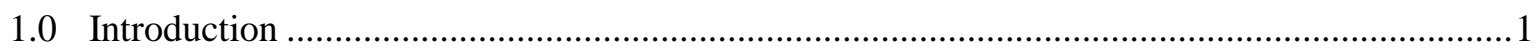

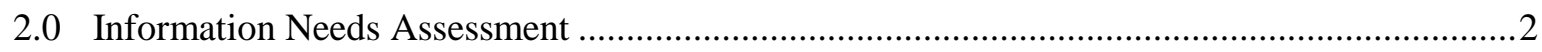

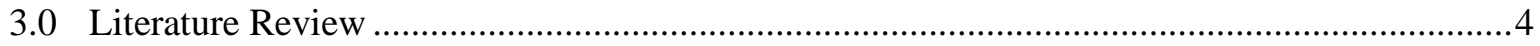

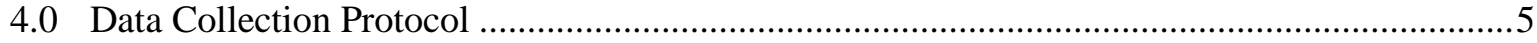





\subsection{Introduction}

As expectations for the built environment change to reflect a deeper concern for sustainability, it is imperative to understand how these changes affect the value proposition for each of the many stakeholders in the life cycle of a building. The financial impact analysis of high performance building (HPB) design and operation practices will inform decisions made across the spectrum of interested parties, from the legislator contemplating the imposition of a new incentive to the tenant, balancing higher rental costs against a potential impact on productivity or the owner trying to maximize the long term profit.

This protocol consists of two linked strategies that drive the data collection and analysis, a top down process to clarify which financial questions and metrics are most valuable to key audiences along with a bottom up data survey to identify currently available information. The data survey will be used to collect available information on the impact and value of the most prominent aspects of HPBs' design, construction, operation, and ownership. The data collection protocol will be used to fill the gaps between what decision makers want to know and what information is currently available. With a more complete understanding of each HPB option's costs and benefits, stakeholders will be better able to determine the most effective HPB strategy for their business needs. 


\subsection{Information Needs Assessment}

The complexity and longevity of a building's life lead to many different people, or groups of people, having a vested interest over the full life cycle of a project. In order to maximize impact, this project, will focus on the following key stakeholders:

- Contractor

- Designer

- Developer

- Investor

- Government

- Insurer

- Lender

- Occupant

- Operator

- Owner

A single entity may in fact fill more than one of the above roles; as well different parties may have similar concerns and questions with respect to the value of HPBs. To better understand how each stakeholder will approach the prospect of being involved in a HPB project, typical questions asked at the outset of a HPB activity were collected. Due to the overlapping nature of the above roles, the typical questions have been grouped below by building life-cycle level to avoid repetition. These questions only represent a starting point for the data collection process and will be added to and modified over the course of the project.

- Pre-design

$\circ$ How will HPB choices impact loan interest rates?

- Design

○ How will materials and equipment choices impact project first costs?

- How will sustainable design practices alter the required material quantities and equipment sizes for a project?

- How will the inclusion of experienced design professionals impact the design costs?

- How will the length of time required for design change?

○ How will integrating the design process impact the projects design costs?

- How will requirements related to site impact alter building costs?

- Construction

$\circ$ What are the costs of special requirements regarding the use and disposal of building materials?

- What sort of procedural changes are required and how much will they cost? 
○ How will requirements related to site impact limit design and construction options?

- What sort of specialized technical labor will be required and how much will it cost?

- What is the impact of HPB construction practices on the time of construction?

- Certification or Public Recognition

- How much does it cost to obtain official certification or recognition?

- Occupation

- How will this building impact the health and productivity of its occupants?

- How will this building impact the physical comfort and well-being of its occupants?

- How will work place desirability impact my retention of staff?

- How will this building help attract clients?

- Operation

- How much energy will a sustainably designed building use compared to a typically designed building?

- How much water will a sustainably designed building use compared to a typically designed building?

- How will maintenance schedules and cost change due to sustainable operation practices?

- What will be the impact on the flexibility of space utilization?

- What will it cost to implement sustainable facilities operation practices?

- Ownership

○ How will a sustainably designed building impact potential rental rates?

- How will a sustainably designed building impact sale listings and the profit from sales?

○ How will a sustainably designed building impact the cost of insurance?

The relationship between stakeholders and the project life-cycle level is complex and generally project specific, though some trends are consistent between projects. For example, it is less common for a facilities operation company to be involved in a project at the pre-design stage or that a developer would play much of a role in the day to day operation of a building. It is also possible that a single entity might fulfill multiple roles over the full course of a project, such as an owner occupier. This complex relationship will generally have to be appraised on a project by project basis. 


\subsection{Literature Review}

To address the issue of finding what information is currently available, a literature survey was performed on the topics of cost estimation for both high performance and typical buildings. There is extensive information available on general building cost estimation, much of which is also useful in costing individual components and some assemblies commonly used in HPBs. These resources mostly cover the design and construction periods of the project life cycle and are generally of most interest to designers and developers. Much less information related to the performance of HPBs through occupation and their impact on owners and occupants was found over the course of the literature survey. The information that was found generally consists of research papers based on specific case studies and require extra effort to make them broadly applicable. A sample of the initial literature review can be found in Appendix A. The literature review is on-going, thus additional resources are being added to this list as they are identified and reviewed. 


\subsection{Data Collection Protocol}

With an initial set of stakeholder interests identified and available literature collected, data gaps highlighting where it currently does not appear to be feasible to respond to key stakeholder questions. In addition to the effort to continue to identify new published resources, this data collection protocol is intended to provide a structure to collect HPB financial data that can be used to fill the knowledge gaps and so respond to stakeholder questions about the cost of HPBs. The data collection plan (Appendix B) will be used to pilot test the protocol, identify further stakeholder questions, and understand whether the indicators used to respond to the questions are useful to HPB decision makers. In the data collection pilot test, the stakeholders will clarify the information they need to make financial decisions regarding sustainably designed buildings, which will further inform the data collection process. The following data collection protocol will be used to address the data gaps identified by stakeholders.

\section{Part A - Identify data requirements and availability}

1. Identify key metric(s) needed to answer stakeholder question(s) and restate the original question(s) in terms of the identified metric(s).

Metric(s) will most often consist of some value (cost, energy use, etc.) that can be used to explain the performance of a building. A sample list of performance metrics for sustainable buildings is available in Appendix C.

2. Identify the primary building and site characteristics that can be used to normalize the above metrics. Example characteristics include location, use type and size (for a more complete sample list of characteristics see Appendix D).

3. Develop a set of pertinent indicators using the metric(s) and characteristics selected above. Indicators allow for direct comparison between buildings by relating a metric to the characteristics of the buildings being compared (for example, cost per gross square foot, water use per occupant, etc.).

4. Using the data sources associated with the selected metrics or indicators develop list of available data and determine if quality and scope is sufficient to answer the initial question(s).

Type 1 - Comprehensive data covering the required metrics and/or indicators is available from a "trusted source", as well as all pertinent building characteristics.

Type 2 - Trustworthy data is available but is incomplete because of missing characteristics information.

Type 3 - Obtaining required information will require extensive original research due either to complete lack of existing data or the unreliability of existing sources.

5. Tag question with a question string to clearly identify data gaps from available data. List data needed to respond to question:

- Indicator(s)

- Metric(s)

- Characteristic(s) 


\section{Part B - Data Collection}

1. For 'type 1' data, use existing data sources to collect information.

a. Extract pertinent metrics, indicators, and characteristics from existing data sources.

b. Use performance data and building characteristics to develop remaining indicators needed to respond to stakeholder question(s).

2. For 'type 2' data, maximize use of existing data and develop plan to collect missing values

a. Using list of available sources clarify what data is needed to finalize data set.

b. Collect data for each metric or indicator where data is available.

c. For each metric without an existing data, follow steps for 'type 3'.

3. For 'type 3' data, develop plan to collect the required information based on the type and desired detail.

a. Perform supplementary literature search targeting the specific metric or indicators of interest.

b. Determine quantity and quality of data needed to respond to question and to develop reusable metric data. It is important to minimize the data required to fully capture the metric of interest, original research/data collection can quickly become a challenge due to unnecessarily broad scope.

c. Identify potential sources that would be able to provide the information needed for the pertinent project characteristics, for example: equipment and/or material suppliers, contractors and/or service providers, technical experts, etc.

d. Solicit required data from sources identified above, analyze and summarize responses in a manner to facilitate extracting useful metrics or indices.

e. Extract metric(s) and/or indices required to answer initial question.

4. Present findings to stakeholder and assess whether results sufficiently address the initial question(s). If information does not meet the stakeholder's expectations, get clarification on data needs and repeat process (i.e., steps one through four).

5. For each pertinent data source and for each metric, produce a single string that contains the following information:

a. Metric name/description

b. Value

c. Units

d. Data source

e. Characteristic descriptions and values

This protocol is intended to provide a simple and flexible framework that will allow for a diverse range of issues to be addressed. It is indented to find and store specific data points regarding HPB costs. The inherent flexibility of the above data collection system will allow for results to be presented in multiple ways, geared to different stakeholder interests and backgrounds. 


\section{Glossary}

Metric: An attribute of a building or project used to characterize and quantify its performance. For example, energy use and cost, water use and cost, and construction cost.

Characteristic: An attribute of a building allowing for the valid comparison of metrics between buildings. For example, floor area, use type, and location.

Indicator: A metric for multiple buildings that have similar characteristics. For example, energy use in large, southern California laboratory buildings, and water use in small office buildings in eastern Washington.

High Performance Building (HPB): Sustainably-designed buildings that integrate and optimize all major high-performance building attributes, including energy efficiency, durability, life-cycle performance, and occupant productivity. ${ }^{1}$

Stakeholder: Interested party in HPB performance and cost. For example, owners, developers, operators, and designers.

\footnotetext{
${ }^{1}$ Adapted from the National Institute of Building Sciences: Definition of High Performance Building per Title IX, Subtitle A, Section 914 of EPACT 2005
} 



\section{Appendix A: Sample of Literature Review}

\begin{tabular}{|c|c|c|c|c|}
\hline Report Name & Author (Publisher) & Pub. Date & Key Findings & $\begin{array}{l}\text { Primary } \\
\text { Audience }\end{array}$ \\
\hline $\begin{array}{l}\text { Value Beyond Cost Savings: } \\
\text { How to Underwrite } \\
\text { Sustainable Properties }\end{array}$ & \begin{tabular}{|l|} 
Scott Muldavin, \\
Green Building \\
Finance Consortium
\end{tabular} & $2010 \mathrm{Feb}$ & $\begin{array}{l}\text { This comprehensive } 300 \text { page book (the initial piece of what will ultimately be more than } \\
700 \text { pages) describes how to address the role of certifications in financial analysis; } \\
\text { presents a Sustainable Property Performance Framework; introduces a Sustainable } \\
\text { Property Cost-Benefit Checklist of the positive and negative risks of sustainability; } \\
\text { financial analysis methodology; details special considerations in the underwriting of } \\
\text { energy efficiency investment and space user demand, and provides specific } \\
\text { recommendations for modifications to underwriting and due diligence guidelines for } \\
\text { sustainable properties. }\end{array}$ & $\begin{array}{l}\text { Owner/Users, } \\
\text { Investors, } \\
\text { Developers, } \\
\text { Appraisers, } \\
\text { Lenders, } \\
\text { Brokers }\end{array}$ \\
\hline $\begin{array}{l}\text { The Economics of Energy } \\
\text { Efficiency in Buildings }\end{array}$ & $\begin{array}{l}\text { The Peterson } \\
\text { Institute for } \\
\text { International } \\
\text { Economics }\end{array}$ & 2009 Nov & $\begin{array}{l}\text { This paper analyzes and supports the results of the WBCSD study - Transforming the } \\
\text { Market (Aug 2009). Conclusions: Reducing building sector emissions by } 8.2 \text { billion } \\
\text { tons will require an additional } \$ 1 \text { trillion investment - however, these costs could be } \\
\text { reduced through technology and economies of scale. Energy cost savings will recover } \\
\text { most, though not all, of these costs. Avg. cost } \$ 25 / \text { ton. A carbon price of } \$ 25 / \text { ton is } \\
\text { insufficient to catalyze the necessary change. Must be coupled with new codes and } \\
\text { standards. How revenue generated from market based climate policy (i.e. carbon tax or } \\
\text { cap \& trade) is used will determine the distributional impact of reducing emissions. } \\
\text { Plowing the revenue back in to improve efficiency will make policy more progressive. }\end{array}$ & $\begin{array}{l}\text { Investors, } \\
\text { Policy Makers }\end{array}$ \\
\hline $\begin{array}{l}\text { Do Green Buildings Make } \\
\text { Dollars and Sense? }\end{array}$ & $\begin{array}{l}\text { Norm Miller, Dave } \\
\text { Pogue }\end{array}$ & $\begin{array}{c}2009 \text { Nov } \\
\text { (Draft) }\end{array}$ & $\begin{array}{l}\text { Some useful data on occupancy rates, rental rates, and characteristics of green building } \\
\text { tenants. } \\
\text { Other measured data (productivity, energy and water costs) questionable. } \\
\text { Found that overall operating expenses were essentially the same for green buildings } \\
\text { compared to conventional buildings (suggests that maintenance and other expenses are } \\
\text { higher in green buildings while energy/water costs are lower) }\end{array}$ & $\begin{array}{l}\text { Owner/Users, } \\
\text { Investors, } \\
\text { Developers, } \\
\text { Appraisers, } \\
\text { Lenders, } \\
\text { Brokers }\end{array}$ \\
\hline
\end{tabular}





\section{Appendix B: Data Collection Plan}

1. Select 1 to 3 stakeholders to interview regarding their dominant HPB cost related interests, and develop questions to address these interests. For example, interviewees may be asked:

- How would you best describe your role(s) throughout the life cycle of a building?

- What are your questions about implementing HPB practices?

- What information do you have regarding the costs associated with HPB practices?

- In your experience, what questions or concerns are most frequently mentioned with respect to the costs and benefits of HPB practices in your industry?

The answers to the above survey will then be used to ensure that all key issues are addressed by the preexisting list of questions or to develop new questions, as needed.

2. Implement protocol

Execute the protocol to address the identified questions. The questions will initially be answered only for projects that have characteristics corresponding to those of the trial users. This limited execution will allow for rapid confirmation of results and facilitate refinement of the protocol. Through the initial protocol implementation and refinement, any problems that arise should be documented and addressed as appropriate.

3. Confirm that the data collection results address stakeholder needs, and if needed continue to collect data to effectively respond to stakeholder question(s).

When the users are satisfied with the answers provided, the scope will be expanded beyond the initial limited range to include all questions and a full range of project characteristics, these factors will include:

- Location

- Use type

- Size

4. Compile protocol implementation issues and modify the protocol as needed.

In addition to the data collection protocol, a framework for data storage and access is needed. This framework will be designed such that users can easily locate desired information, or make requests for new and/or additional information. 



\section{Appendix C: Performance Metrics}

Sample performance metrics that have been used to collect whole building performance measurement data for the Federal sector. Source: K.M. Fowler, et al. 2009. Whole Building Cost and Performance Measurement: Data Collection Protocol, Revision 2. PNNL-18325. Pacific Northwest National Laboratory, Richland, Washington.

URL: http://www1.eere.energy.gov/femp/program/sustainable_resources.html\#bcpm

\begin{tabular}{|c|c|c|}
\hline Metric & Required & Optional \\
\hline Water & Total Building Water Use & $\begin{array}{l}\text { Indoor Water Use } \\
\text { Outdoor Water Use } \\
\text { Process Water Use } \\
\text { Total Storm Sewer Output }\end{array}$ \\
\hline Energy & Total Building Energy Use & $\begin{array}{l}\text { Source Energy } \\
\text { Peak Electricity Demand } \\
\text { On-site Renewable Energy } \\
\text { Special Equipment }\end{array}$ \\
\hline $\begin{array}{r}\text { Maintenance \& } \\
\text { Operations }\end{array}$ & $\begin{array}{l}\text { Building Maintenance } \\
\text { Preventative Maintenance }\end{array}$ & $\begin{array}{l}\text { Grounds Maintenance } \\
\text { Janitorial Maintenance } \\
\text { Churn Costs }\end{array}$ \\
\hline $\begin{array}{r}\text { Waste Generation } \\
\text { and Recycling }\end{array}$ & Solid Sanitary Waste & $\begin{array}{l}\text { Recycled Materials } \\
\text { Hazardous Waste }\end{array}$ \\
\hline $\begin{array}{r}\text { Indoor } \\
\text { Environmental } \\
\text { Quality }\end{array}$ & $\begin{array}{l}\text { Building Occupant } \\
\text { Satisfaction }\end{array}$ & $\begin{array}{l}\text { Self-rated Productivity } \\
\text { Absenteeism } \\
\text { Turnover Rate } \\
\text { Indoor Air Quality }\end{array}$ \\
\hline Transportation & Regular Commute & Business Travel \\
\hline
\end{tabular}





\section{Appendix D: Building and Site Characteristics}

Sample building and site characteristics that have been used to collect whole building performance measurement data for the Federal sector. Source: K.M. Fowler, et al. 2008. Whole Building Cost and Performance Measurement: Data Collection Protocol, Revision 2. PNNL-18325. Pacific Northwest National Laboratory, Richland, Washington.

URL: http://www1.eere.energy.gov/femp/program/sustainable_resources.html\#bcpm

\begin{tabular}{|c|c|c|}
\hline & Required & Optional \\
\hline \multirow{6}{*}{$\begin{array}{l}\text { Building } \\
\text { Specifications }\end{array}$} & Building Location & Gross Ground Floor Footprint/Number of Floors \\
\hline & Building Function & Gross Conditioned Floor Area \\
\hline & $\begin{array}{l}\text { Key Building Features/ } \\
\text { Design Intent }\end{array}$ & Parking Area \\
\hline & $\begin{array}{c}\text { Year Building First Occupied } \\
\text { or Year of Last Major } \\
\text { Renovation }\end{array}$ & Ratings or Awards \\
\hline & Gross Interior Floor Area & Landscaped Area \\
\hline & Operational Concerns & Total Building Site Area \\
\hline \multirow[t]{5}{*}{ Occupancy } & Type of Occupant & $\begin{array}{c}\text { Key Policies (e.g. sick leave, holidays/vacations, } \\
\text { recycling, transportation, etc.) }\end{array}$ \\
\hline & Hours of Operation & \\
\hline & $\begin{array}{c}\text { Total Number of Regular } \\
\text { Occupants }\end{array}$ & \\
\hline & Number of Regular Visitors & \\
\hline & Occupant Gender Ratio & \\
\hline \multirow[t]{3}{*}{ First Costs } & Total Building Cost & Design Cost \\
\hline & & Construction Cost \\
\hline & & Unusual Cost Elements \\
\hline
\end{tabular}




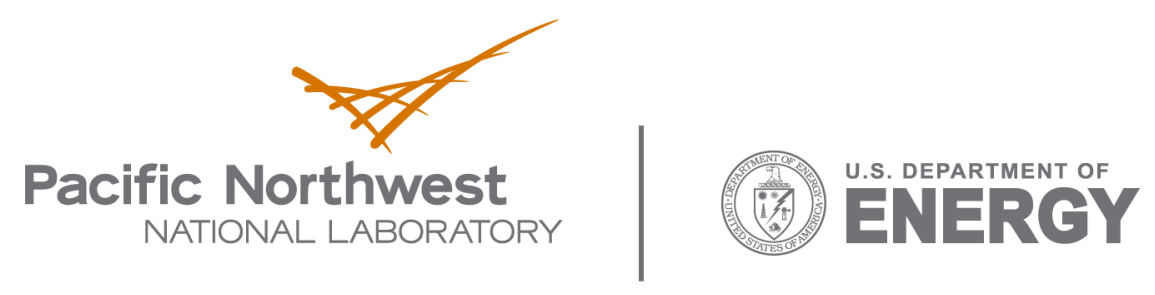

902 Battelle Boulevard

P.O. Box 999

Richland, WA 99352

1-888-375-PNNL (7665)

www.pnl.gov 